grown above the roots of the tree in the ordinary way. The conditions of the experiment seem to have precluded any sufficient contact of the grass roots with the tree soil to allow of the abstraction of plant food, and, if the result is confirmed, it is difficult to avoid the conclusion that the grass roots have actually excreted a toxin.

As already stated, the United States Bureau of Soils has long upheld the view that plants can excrete toxic substances, but it has been generally supposed, in this country at any rate, that the experiments of Daubeny and others put the hypothesis out of court. But Mr. Pickering has discovered an important property which the toxin (if it exists) must possess; it is extremely transient, and disappears very rapidly from the soil. No toxic effect can be detected in soil removed from round grass roots, while even the washings from the trays above mentioned failed to have any bad effect if they were exposed for a short time to air.

A very interesting problem has been thus opened up, the development of which will be watched with interest.

E. J. R.

THE BIRDS OF HOMER.

THE advantages of the application of scientific knowledge to the literary problems of the Homeric poems are well illustrated by an article contributed to the second part of the "Journal of Hellenic Studies" for I9II, by Mr. J. Maclair Boraston on "The Birds of Homer." He remarks that "whether in the form of epithet or by special description, Homer's portrayal of birds deals chiefly with essentials. In this lie the advantage and disadvantage of the Homeric method for one whose main purpose is concerned with what in Homer was merely contributory to a fuller one. The advantage of such a method is that it forces essentials to the front, and the disadvantage, that the references to these may be limited by the nature of the matter they serve to illustrate; or that, being references to the characteristics of a class of birds, they may not suffice for the illustration of a particular member of that class."

Dealing first with what Homer calls "carnivorous birds," we find three mentioned; the first represented by the bearded vulture (Gypaëtus barbatus), the second and third including the cinereous vulture (Gyps monachus), the griffon vulture (G. fulvus), and the Egyptian vulture (Neophron percnopterus). The poet describes three eagles-" the high-flyer" and the "ruddy," both apparently Bonelli's eagle (Hieraëtus fasciatus) in mature and immature plumage, while the "morphnos" or "perknos" eagle, the "black" or "dark," and the "snatcher" are all names for the golden eagle (Aquila chrysaëtus). The general terms for the hawk or falcon include several birds-the goshawk (Astur palumbarius), the sparrow-hawk (Accipiter nisus), the peregrine falcon (Falco peregrinus), the lanner ( $F$. lanarius), the saker ( $F$. sacer $)$, the merlin ( $F$. aesalon), and the hobby ( $F$. subbuteo). Two varieties of owl are identified with the scops (Scops giu) and the long-eared owl (Asio otus). Under gulls Homer refers to no fewer than eight varieties, all found at the present day in the Mediterranean. The "diving seabird" includes various kinds of terns, chiefly the common tern (Sterna fluviatilis). Under the head of cranes we find the common crane (Grus communis), and the demoiselle (G. virgo). Swans include the mute swan (Cygnus olor) and the whooper (C. musicus). Of geese we have the grey lag (Anser cinereus), the bean goose ( $A$. segetum), and others. Among miscellaneous birds we notice the grey heron (Ardea cinerea); the jackdaw (Corvus monedula); the NO. 2206 , VOL. 88$]$ starling (Sturnus unicolor and $S$. vulgaris); the rock dove (Columba livia); three thrushes-the fieldfare (Turdus pilaris), the missel thrush (T. viscivorus), and the redwing ( $T$. iliacus); the common nightingale (Daulias luscinia); the great titmouse (Parus major); and the ring-dove (Columba palumbus).

Mr. Boraston's article records a number of interesting details illustrative of bird-life in the Mediterranean, which will be welcome not only to ornithologists but to classical students, and a survey of the facts which he has collected tends only to increase our admiration for the genius and powers of accurate observation possessed by the greatest of the epic writers.

\section{SIR JOHN DALRYMPLE-HAY, BART., G.C.B., F.R.S.}

A DMIRAL THE RIGHT HON. SIR JOHN DALRYMPLE-HAY, Bart., G.C.B., F.R.S., was born in Edinburgh on February 11,1821 , and died in London on January 28. His naval career was commenced in August, 1834 , and he was placed on the retired list in $18 \% 0$, under Mr. Childers's scheme, having attained flag rank as Rear-Admiral about four years earlier, and having occupied various offices on shore after ceasing to command … the line-ofbattle ship Indus in '1859.' His active 'service afloat, therefore, 'seased 'in 'the year when our first seagoing ironclads were ordered. During the thirty-six years comprised in : that service he " had witnessed the change from sails $\cdot$ to steam propulsion, serving: nearly all the time in wood-built sailing ships, and having commanded, as captain; the Indus, which was the last sailing line-of-battle ship in seagoing commission.- Sir-John-Hay was present at the capture of Acre by Sir Rupert Stopford; and later (I849) greatly distinguished himself by the destruction of a pirate flotilla in China. The latter service secured for him promotion to the rank of captain; and in 1855-6 he commanded the Hannibal, the flagship of Sir Houston Stewart, second in command of the Black Sea Fleet during the Crimean. War.

When Kinburn was bombarded by the French ironclad floating batteries, Sir John Hay was present, and then obtained personal knowledge of the value of anrour as a protection against the attacks of the thost powerful naval guns and shell-fire available at that date. It was natural, therefore, that he should have been appointed chairman of the Iron-plate Committee which. was established in 1860 to carry out experiments on armour, and to investigate the innumerable proposals and inventions submitted for adoption in the Royal Navy. In a period of rapid change and transition in naval matériel it was a wise step to appoint that committee, and to associate in its membership both distinguished officers and eminent engineers and men of science--including Sir William Fairbairn; Dr. Percy, and Dr. Pole-whose authority on questions of metallurgy and engineering was generally recognised, while their advice and assistance in the conduct of experiments and the analysis of results were of great value.

In his conduct of the affairs of this committee, Sir John Hay displayed great tact and marked ability, often in circumstances of considerable difficulty, inventors being both sensitive and ready to take offence when their proposals were criticised or rejected. Recognition of the value of his work came to $\mathrm{Si}_{i} \mathrm{~J}$ ohn Hay from technical and scientific societies; he was elected a vice-president of the Institution of Naval Architects in 1862 , and a Fellow of the Royal Society in I864. Throughout his long life Sir John Hay continued to take an active interest in both these societies, and in connection with the Naval Architects he played 
a prominent part until failing health compelled him to retire. In the conduct of the business, as well as in the discussion of professional subjects, his ripe experience, sound judgment, and charming personal qualities had much to do with the successful development of the institution, the membership of which includes not merely naval architects and marine engineers, but naval officers, shipowners, yachtsmen, officers of the mercantile marine, and many other classes interested in or connected with shipping.

At the Royal United Service Institution also Sir John Hay did good service, and gave proof of his love for and acquaintance with many branches of science, as well as his desire to utilise all departments of knowledge for the improvement of the Royal Navy. In short, for a man born early in the nineteenth century, and employed at sea from a tender age until he had reached the prime of life, Sir John Hay was remarkable; and he may be fairly described as a pioneer in the class of scientific naval officers which has now become both numerous and influential.

Of his political career this is not the place to speak, but allusion may be made to his services as a Sea Lord of the Admiralty in I866-8. Although the appointment of Sea Lords was then made largely on political as well as professional grounds, and his political future might have been seriously prejudiced by the independent action which he took in November, I866, he refused to sign the Navy Estimates, and tendered his resignation because he considered the new programme of shipbuilding to be inadequate. This action showed the temper of the man, who, under a most pleasant and conciliatory manner, concealed great strength of character and readiness to act up to his convictions. His business capacity was considerable, he was a capable speaker, and an agreeable writer, as his books dealing with the naval service showed. He died full of years and honours, mourned by many friends; but some years of retirement, accompanied by blindness towards the end, had prevented him from being so much before the public as formerly. His work was done and well done, and many of its results will abide.

\section{DR. A. H. KEANE.}

$W^{E}$ regret to announce the death of Dr. A. H. Keane on February 3, after a long illness. $\mathrm{He}$ was born in Cork in 1835, was educated in Dublin and elsewhere, and completed his student career in Rome, finally taking his degree with honours in the Roman Catholic College in Dublin. Later he studied in Germany, and thereafter devoted himself to literary work, his first important book being a "History of the English Language" (1878). Shortly afterwards he taught English, German, French, and Hindustani at the Hartley. Institute, Southampton, and subsequently a professorship of Hindustani was created for him at University College, London, which he resigned in 1885 . After a short visit to the United States, he settled down in Hampstead, where he resided until his death.

Anthropology loses in Dr. Keane one of its most prolific and erudite students. His literary training and great command of languages predisposed him to collation and synthesis, as is proved by several excellent studies in the Journal of the Anthropological Institute; for example, "On the Relations of the IndoChinese and Inter-Oceanic Races and Languages" (I880), "The Botocudos" (I883), "The Ethnology of the Egyptian Sudan", (1884), "The Lapps" (I885), and others. He also contributed very numerous articles on ethnology to Nature, The Geographical Journal, The Academy, NO. 2206 , VOL. 88]
The Encyclopaedia Britannica (ninth edition), Chambers's Encyclopaedia (1890-1), and Cassell's Storehouse of General Information (1890-94). Of more permanent value are his admirable monographs on Asia, Africa, Central America and West Indies, and South America in "Stanford's Compendium of Geography and Travel." Amongst other publications are "The Boer States, Land, and People" (1900), "The Gold of Ophir" (I9OI), and numerous translations, as, for example, "The Earth and its Inhabitants" (Elisée Reclus), "Peruvian Antiquities" (W. Reiss and A. Stübel), "The Science of Language" (Abel Hovelacque), "Philosophy, Historical and Critical" (A. Lefèvre), "Travels in Africa" (W. Junker), and "The Second Deluge" (J. Rodenberg).

But.Dr. Keane's reputation will rest mainly on his "Ethnology" (1806), "Man Past and Present" (1899), and "The World's Peoples" (r908). The first deals with the physical and mental evolution of man, the antiquity of man, criteria of race, and the primary ethnical groups. The second is a masterly summary of the ethnology of all races and peoples, and is an indispensable book to all interested in such subjects. The third, as its subtitle explains, is a popular account of the bodily and mental characters, beliefs, traditions, and political and social institutions of the world's peoples; the numerous photographs add greatly to its value.

Dr. Keane was a typical library student, and being of retiring disposition, was rarely to be seen at scientific meetings. He had strong views and could express them with vigour, but he did not seek controversy. Although lack of opportunity prevented him from making any original investigations, the vast extent of his reading enabled him to marshal in an orderly manner the observations of other people, and often to throw a fresh light upon them.

\section{A. C. HADDON.}

\section{NOTES.}

We regret to announce the death, on February 2, in his sixtieth year, of Dr. H. T. Bovey, F.R.S., formerly Rector of the Imperial College of Science and Technology.

M. Bigourdan has been elected president of the Paris Bureau des Longitudes for the present year. M. Baillaud becomes vice-president, and M. Andoyer secretary.

The gold medal of the Royal Astronomical Society has been awarded by the council to Mr. A. R. Hinks, for his determination of the solar parallax from observations of Eros.

The Canadian correspondent of The Times announces the death, at eighty-seven years of age, of Sir James Le Moine, who for many years was an industrious writer on historical and ornithological subjects, and in 1894 was elected president of the Royal Society of Canada.

REUTER's AGENCY reports that two British officers, one belonging to the Survey of India, have been detached to locate the falls of the Brahmaputra, which are reputed to exist in the hitherto unexplored reach of the river which lies between Assam and the great bend of the river to the northward. Attempts have been made by native surveyors and others to locate these falls and to traverse this part of the river where its valley cuts across the great Himalayan chain, but so far without any success.

Further evidence shows that, of the four reported earthquakes referred to in our last issue (p. 459), that felt in Glenfruin on January 26 was probably not of seismic origin. The shocks at Lennoxtown on January 20 and 